\title{
new from sage!
}

SOVIET

QUANTITATIVE

HISTORY

odited by DON KARL ROWNEY, Department of History, Bowling Green State University

\section{Foreword by Theodore K. Rabb}

Published in cooperation with the Social Science History Association

The first book in the English language to demonstrate the meanings and methods of Soviet quantitative history. Through historical perspectives, renowned Russian scholars analyze Soviet quantitative research approaches. While quantitative historians will discover new modes of data collection and analysis, specialists in Slavic and Russian history will gain fascinating insights into the economic and social background of the country. Editor Don Karl Rowney provides a lengthy introduction, placing the articles in context for the nonspecialist. All Western scholars will find Soviet Quantitative History a rare glimpse into an important research tradition.

CONTENTS: Preface STANLEY L. ENGERMAN / Foreword: The SovietAmerican Exchange in Quantitative History THEODORE K. RABB/1. Soviet Quantitative History DON KARL ROWNEY / 2. Model-Building for Historical Phenomena and Processes IVAN KOVAL'CHENKO/3. Large Data Files and Quantitative Methods in the Study of the Agrarian History of Russia IV AN KOVAL'CHENKO \& N. SELUNSKAIA / 4. Quantitative Methods and Research on the History of the Traditional Soviet Peasantry IU. P. BOKAREV/ 5. Studying Cycles of Agrarian Development Through Pattern Recognition Methods J. KAHK \& MART REMMEL / 6. Quantitative Methods of Research on Sociocultural Processes in the Development of Soviet Peoples IU. V. ARUTIUNIAN / 7. Large Data Sources and Methods of Their Analysis in the History of the Soviet Working Class and Intelligentsia V.Z. DROBIZHEV \& E.I. PIVOVAR / 8. Some Aspects of the Application of Quantitative Methods and Computers in the Analysis of Narrative Texts L.I. BORODKIN \& L.V. MILOV / Index

New Approaches to Social Science History, Volume 4 1984 (January) / 216 pages / $\$ 25.00$ (h) 
by ALLAN G. BOGUE, Frederick Jackson Turner Professor of History, University of Wisconsin-Madison

\section{Published in cooperation with the \\ Social Science History Association}

Decades ago when quantitative history was still in its infancy, a president of the American Historical Association warned followers of the History Muse, Clio, never to "worship at the shrine of that bitchgoddess, quantification."

Allan G. Bogue is a central figure in the quantitative revolution that has since transformed historical scholarship. The essays in this volume provide an account of the sources, objectives, and techniques of cliometrics; sketches of leading personalities in the movement; commentary on its successes and failures; and fresh insights into the way major methodological innovations are entering mainstream historical research. Together, they comprise a provocative overview of the historical development-and basic principles-of rigorous empirical analysis in American Political History.

"This book is a guide to good historiographic practices for all historians.... It is a reasoned argument for a return, on a new and higher level, to old concerns for the quality and reliability of evidence, and for more careful attention to the inferences that particular bodies of evidence can support. ... Cliometric approaches to such matters as "sampling bias," "model misspecification," and "data gaps" have, [Bogue] shows, applicability to virtually every type of historical evidence."

-from the Introduction by Robert Fogle, University of Chicago Business School

CONTENTS: Foreword ROBERT FOGLE/Introduction// I. Beginnings//1. Inside the "Iowa School" // II. The "New" Political History // 2. United States: The "New" Political History / 3. Recent Developments in Political History: The Case of the United States / 4. The New Political History in the 1970s // III. Archival Issues // 5. The Historian and the Social Science Data Archives in the United States / 6. Data Dilemmas: Quantitative Data and the Social Science History Association / 7. Historical Research and State Archival Data//IV. The Place of Quantification and Quantitative Evidence // 8. Numerical and Formal Analysis in United States History / 9. Historians and Radical Republicans: A Meaning for Today

New Approaches to Social Science History, Volume 3

1983 (October) / 280 pages / $\$ 28.00$ (h) / $\$ 14.00$ (p) 